\title{
Sources of organic trace minerals in diets for weaned piglets
}

\author{
Gabriela de Mello ${ }^{1}$, Dirlei Antonio Berto ${ }^{2}$, Vivian Lo Tierzo², Regina Maria Nascimento \\ Augusto $^{2}$, Anália Maria Ribeiro da Silva ${ }^{3}$, Messias Alves da Trindade Neto ${ }^{4}$, Cássio Cordeiro \\ Ensá Junqueira Villela², Lúcio Vilela Carneiro Girão
}

\footnotetext{
${ }^{1}$ Departamento de Produção Animal da FMVZ- UNESP/ Botucatu, SP, Brazil. Fellow from FAPESP.

${ }^{2}$ Departamento de Produção Animal da FMVZ- UNESP/ Botucatu, SP, Brazil.

3 Tortuga Cia. Zootécnica Agrária.

${ }^{4}$ Departamento de Produção e Nutrição Animal da FMVZ-USP, SP, Brazil.
}

\begin{abstract}
One hundred and twenty six piglets from a commercial genetic strain weaned at 21 days of age $(6.11 \pm 0.42 \mathrm{~kg})$ were used to evaluate the effects of supplementation levels of organic sources of trace minerals in the diets of weaned piglets on performance, occurrence of diarrhea, excretion of copper and zinc in the feces, and hematological parameters. A completely randomized block design was adopted, composed of six treatments (diets containing 100\% of inorganic trace minerals premix at $3.00 \mathrm{~kg} / \mathrm{T}$; diets containing $0,25,50,75$ or $100 \%$ of organic trace minerals premix, equivalent to $0 ; 0.75 ; 1.50 ; 2.25$ or $3.00 \mathrm{~kg} / \mathrm{T}$, respectively), seven replicates and three animals per plot. During the experimental period (from 21 to 63 days of age), the increasing levels of organic trace minerals premix in the diets determined a quadratic effect on daily weight gain (DWG), feed conversion (FC), percentage of hematocrit (Ht), hemoglobin (Hb), mean corpuscular hemoglobin (MCH), mean corpuscular volume (MCV), platelets $(\mathrm{Pt})$, and a linear increase of $\mathrm{Cu}$ and $\mathrm{Zn}$ concentrations in feces. The comparison of means between the treatment with inorganic trace minerals premix and the other treatments showed that piglets fed diets without trace minerals premix had lower values of DWG, $\mathrm{Ht}, \mathrm{Hb}, \mathrm{MCH}, \mathrm{MCV}, \mathrm{Pt}$ and the worst $\mathrm{FC}$ value of piglets fed diets containing $25 \%$ of organic trace minerals premix presented lower values of $\mathrm{Ht}$ and $\mathrm{Hb}$, in comparison with those fed diets with $100 \%$ of inorganic trace minerals premix. Inorganic trace minerals premix can be substituted by organic trace minerals premix at a lower level of inclusion in diets for weaned piglets.
\end{abstract}

Key Words: diarrhea, hematological parameters, pigs, performance

\section{Introduction}

The variations in the bioavailability of minerals in the sources, the actions of synergism or antagonism existing between minerals and environmental issues have drawn the interest of researchers in alternatives that result in lower excretion by the animals (Muniz, 2007).

Excessive minerals in the diet are not processed by the organism of the animal, so they are excreted in feces and urine, thus causing pollution to the environment.

Mineral elements can be provided to pigs through saline inorganic and organic methods, concerning the latter, due to a higher offer in the animal nutrition market and a deepening of research studies about the participation of trace minerals in general performance and animal health, its use is increasing.

Therefore, the objective of the present investigation was to evaluate the effects of supplementation levels of trace minerals organic sources $(\mathrm{Fe}, \mathrm{Cu}, \mathrm{Mn}, \mathrm{Se}$ and $\mathrm{Zn}$ ) in the diets under performance, occurrence of diarrhea, excretion of copper and zinc in feces and hematological parameters of weaned piglets.

\section{Material and Methods}

The trial was conducted at Universidade Estadual de São Paulo - UNESP, in nursery facilities of the Escola de Medicina Veterinária e Zootecnia, in Botucatu, Brazil.

One hundred and twenty-six commercial hybrid (barrows and females) piglets weaned at 21 days of age with live weight of $6.11 \mathrm{~kg} \pm 0.42$ were used. Piglets were allotted in suspended pens with slatted floor (three animals per pen), equipped with feeder, drinker (nipple type) and hood with electrical resistance. Curtains were installed on the sides to keep internal ventilation of the facility and a maximum and minimum thermometer was installed at a height of $0.80 \mathrm{~m}$ from the floor of pens to assist the daily control of the heating sources.

A completely randomized block design was adopted, composed of six treatments, seven replicates and three animals per plot. Treatments were: basal diet (BD) without the inclusion of organic trace minerals premix and inorganic trace minerals premix; BD with $25 \%$ of inclusion of organic trace minerals premix $(0.75 \mathrm{~kg} / \mathrm{T})$; BD with $50 \%$ 
of inclusion of organic trace minerals premix $(1.50 \mathrm{~kg} / \mathrm{T})$; BD with $75 \%$ of inclusion of organic trace minerals premix $(2.25 \mathrm{~kg} / \mathrm{T})$; BD with $100 \%$ of inclusion of organic trace minerals premix $(3.00 \mathrm{~kg} / \mathrm{T})$; BD with $100 \%$ of inclusion of inorganic trace minerals premix $(3.00 \mathrm{~kg} / \mathrm{T})$. Mineral premixes were added to the basal diets as a substitute for ground rice hulls.

The mineral premixes were elaborated by a commercial company for research purposes and for treatments containing $100 \%$ of supplementation $(3.00 \mathrm{~kg} / \mathrm{T}$ of diet), the firm provided the minerals, with the exception of manganese, at levels that met the recommendations of supplementation proposed by Rostagno et al. (2005), for piglets in the weaning phase (Table 1).

The analysis of trace minerals in the raw material of diets, mineral premixes and feces were conducted at Centro de Apoio Químico ao Ensino, à Pesquisa e de Prestação de Serviços (CEAQUIM) from the Instituto Botucatu de Biociências - IBB.

The experimental period was composed of 42 days (from 21 to 63 days of age), in which piglets received three types of diet, in accordance with the feeding system divided by phases: Pre-starter diet, from 0 to 17 days (21 to 38 days of age); starter diet 1, from 18 to 32 days (39 to 53 days of age); and starter diet 2, from 33 to 42 days of age (54 to 63 days of age). Diets were formulated to meet the nutritional requirements proposed by Rostagno et al. (2005) for each one of the studied phases and supplied to the animals ad libitum (Tables 2 and 3 ).

The mean data of daily feed intake, daily weight gain and feed conversion in the periods $0-14,0-32$ and $0-42$ days post-weaning, and the occurrence of diarrhea in the first 14 days of the experimental period were evaluated through verification by a single observer of the consistency of feces of the animals in the morning period. Feces were classified as normal, pasty or liquid (diarrhea).

During the 39th and 40th days of the experimental period, feces on the floor in each one of the pens were collected in the morning and in the afternoon $(07 \mathrm{~h} 30 \mathrm{~min}$ and $05 \mathrm{~h} 30 \mathrm{~min})$. Feces were wrapped in properly identified

Table 1 - Levels of minerals in the premixes and experimental diets

\begin{tabular}{|c|c|c|c|c|}
\hline $\begin{array}{l}\text { Mineral } \\
(\mathrm{mg} / \mathrm{kg})\end{array}$ & $\begin{array}{c}\text { Inorganic } \\
\text { premix }^{1}\end{array}$ & $\begin{array}{l}\text { Organic } \\
\text { premix }^{2}\end{array}$ & $\begin{array}{c}\text { Diets with } \\
\text { inorganic } \\
\text { premix }^{1}\end{array}$ & $\begin{array}{c}\text { Diets with } \\
\text { organic } \\
\text { premix }^{2}\end{array}$ \\
\hline Iron & 34200.00 & 27000.00 & 102.60 & 81.00 \\
\hline Copper & 5500.00 & 4500.00 & 16.50 & 13.50 \\
\hline Manganese & 16200.00 & 15800.00 & 48.60 & 47.40 \\
\hline Selenium & 97.60 & 101.20 & 0.29 & 0.30 \\
\hline Zinc & 58700.00 & 56200.00 & 176.10 & 168.60 \\
\hline
\end{tabular}

${ }^{1}$ Evaluated values

${ }^{2}$ Diets containing $3.00 \mathrm{~kg} / \mathrm{T}$ of trace minerals premix. plastic bags and then frozen. At the end of the collection period, feces which were collected in each one of the pens were defrosted at ambient temperature, dried in a forced circulation oven at $55^{\circ} \mathrm{C}$ for 72 hours and then ground and analyzed for the contents of copper and zinc. Samples of blood from all the animals were collected after the last weighing for evaluation of hematological parameters. Blood sample was collected in the vena cava through a system of vacuum blood sampling $(5 \mathrm{~mL}$ tubes containing EDTA solution at 3\%) with 40X9 needles. Samples were sent to the Laboratory of Veterinary Analysis located in the city of Botucatu, São Paulo State, Brazil, for analysis of hematological parameters.

The counting of erythrocytes and leukocytes, hematimetric indexes as mean corpuscular volume (MCV), mean corpuscular hemoglobin $(\mathrm{MCH})$ and the concentration of mean corpuscular hemoglobin $(\mathrm{CMCH})$ and counting

Table 2 - Composition of pre-starter, starter 1 and starter 2 diets

\begin{tabular}{|c|c|c|c|}
\hline Ingredients ( $\mathrm{g} / \mathrm{kg}$ fed basis) & Pre-starter & Starter 1 & Starter 2 \\
\hline Corn & 420.000 & 500.000 & 630.000 \\
\hline Soybean meal & 150.000 & 220.000 & 270.000 \\
\hline Extruded corn & 85.127 & 0.000 & 0.000 \\
\hline Full fat extruded soybean & 78.000 & 90.000 & 45.000 \\
\hline Milk replacer ${ }^{1}$ & 112.000 & 30.000 & 0.000 \\
\hline Sugar & 14.963 & 15.363 & 7.113 \\
\hline Soybean oil & 0.000 & 10.000 & 13.000 \\
\hline Milk replacer ${ }^{2}$ & 66.000 & 55.000 & 0.000 \\
\hline Maltodextrin $^{3}$ & 20.000 & 30.000 & 0.000 \\
\hline Ground rice hulls ${ }^{4}$ & - & - & - \\
\hline Limestone & 6.600 & 7.300 & 6.600 \\
\hline Dicalcium phosphate & 16.700 & 15.000 & 14.000 \\
\hline Calcium iodate & 0.002 & 0.002 & 0.002 \\
\hline Sodium chloride & 3.200 & 4.000 & 4.700 \\
\hline L-lysine $\mathrm{HCl} 78 \%$ & 7.300 & 5.300 & 3.400 \\
\hline DL-methionine $99 \%$ & 1.540 & 1.000 & 0.500 \\
\hline L-threonine $98 \%$ & 3.000 & 1.900 & 0.800 \\
\hline L-tryptophan 98\% & 0.600 & 0.250 & 0.000 \\
\hline Choline chloride $60 \%$ & 0.635 & 0.635 & 0.635 \\
\hline Sweetener $^{5}$ & 0.150 & 0.150 & 0.150 \\
\hline Flavoring $^{6}$ & 0.300 & 0.300 & 0.300 \\
\hline Antioxidant $^{7}$ & 0.050 & 0.050 & 0.050 \\
\hline Fumaric acid & 10.00 & 8.000 & 0.000 \\
\hline Inorganic minerals premix ${ }^{4}$ & - & - & - \\
\hline Organic minerals premix ${ }^{4}$ & - & - & - \\
\hline Vitamin premix ${ }^{8}$ & 0.500 & 0.500 & 0.500 \\
\hline Oxytetracycline and tiamulin ${ }^{9}$ & - & 2.000 & - \\
\hline Halquinol $60 \%{ }^{10}$ & 0.333 & 0.250 & 0.250 \\
\hline
\end{tabular}

${ }^{1}$ Nuklospray K11, commercial product of Sloten.

${ }^{2}$ Nuklospray K21, commercial product of Sloten.

${ }^{3}$ Argo MD 20, commercial product of Corn Products Brasil

${ }^{4}$ Levels of inclusion variables in function of treatments.

${ }^{5}$ Sucran, commercial product of Pancosma.

${ }^{6}$ Nursing S 44443-Z, commercial product of Lucta.

${ }^{7}$ Oxy-Nil Dry, commercial product of Inve.

${ }^{8}$ Vitamin premix providing the following quantities per kg of diet: vit. A - 9,000 UI vit D3 - 2,250 UI; vit. E - $22.5 \mathrm{mg}$; vit. K3 - $22.5 \mathrm{mg}$; vit. B1 - $2.03 \mathrm{mg}$; vit. B2 - $6 \mathrm{mg}$; vit. B6 - $3 \mathrm{mg}$; vit. B12 - $30 \mathrm{mcg}$; folic acid - $0.9 \mathrm{mg}$; pantothenic acid - $14.03 \mathrm{mg}$; niacin - $30 \mathrm{mg}$; biotin - $0.12 \mathrm{mg}$; choline - $400 \mathrm{mg}$.

${ }^{9}$ Oxytetracycline hydrochloride $(10 \%)$ and Tiamulin hydrogenated fumarate $(3.5 \%)$,

Denagard OT, commercial product of Novartis.

${ }^{10}$ Growth promoter, commercial product of Mcassab. 
Table 3 - Calculated nutritional composition of pre-starter, starter 1 and starter 2 diets ${ }^{1}$

\begin{tabular}{lccc}
\hline Calculated nutritional levels & Pre-starter & Starter 1 & Starter 2 \\
\hline Metabolizable energy $(\mathrm{kcal} / \mathrm{kg})$ & 3376 & 3345 & 3290 \\
Crude protein $(\mathrm{g} / \mathrm{kg})^{2}$ & 184.9 & 195.3 & 195.1 \\
Digestible lysine $(\mathrm{g} / \mathrm{kg})$ & 14.2 & 13.3 & 11.6 \\
Digestible methionine $(\mathrm{g} / \mathrm{kg})$ & 4.0 & 3.7 & 3.2 \\
Digestible threonine $(\mathrm{g} / \mathrm{kg})$ & 9.1 & 8.4 & 7.2 \\
Digestible tryptophan $(\mathrm{g} / \mathrm{kg})$ & 2.5 & 2.3 & 2.0 \\
Calcium $(\mathrm{g} / \mathrm{kg})$ & 8.5 & 8.0 & 7.2 \\
Total phosphorus $(\mathrm{g} / \mathrm{kg})$ & 6.8 & 6.3 & 6.0 \\
Available phosphorus $(\mathrm{g} / \mathrm{kg})$ & 5.0 & 4.4 & 3.9 \\
${ }^{1}$ Values calculated based on nutritional levels presented by Rostagno et al. (2005) or \\
by the manufacturers of the raw materials. \\
${ }^{2}$ Values expressed in on a g/kg fed basis.
\end{tabular}

of platelets $(\mathrm{Pt})$ was done by the automatic hematology analyzer AH-22 USPBR. The percentage of hematocrit was obtained by the derived calculation of the MCV and erythrocyte through impedance, and the hemoglobin was obtained by spectrophotometry.

Data was submitted to analysis of variance using PROC GLM of SAS (Statistical Analysis System, version 6.11), and the effects of supplementation levels of organic trace minerals were studied through regression analysis. For comparison of the results obtained between the treatment with inorganic trace minerals premix with the others, the test of Dunnett - Hsu was applied.

\section{Results and Discussion}

Increasing levels of organic trace minerals premix in the diets determined a linear increase $(\mathrm{P}<0.05)$ in the daily weight gain $\left(\mathrm{DWG}=333.2571+0.2686 \mathrm{X}, \mathrm{r}^{2}=0.39\right)$ and a linear reduction $(\mathrm{P}<0.01)$ in feed conversion $(\mathrm{FC}=1.6981$ $\left.-0.0012 \mathrm{X}, \mathrm{r}^{2}=0.24\right)$ in the period from 21 to 53 days of the age (Table 4).

During all the experimental period (21 to 63 days of age), a quadratic effect of the levels of organic trace minerals premix was verified $(\mathrm{P}<0.01)$ on daily weight gain $\left(\mathrm{DWG}=383.6694+2.3950 \mathrm{X}-0.0181 \mathrm{X} 2, \mathrm{r}^{2}=0.59\right)$ and feed conversion $(\mathrm{FC}=1.7651-0.0049 \mathrm{X}+0.0004 \mathrm{X} 2$, $\left.r^{2}=0.48\right)$, and the best estimated level was $65 \%$ of the recommended inclusion, and linear effect $(\mathrm{P}<0.05)$ was observed on daily feed intake $(\mathrm{DFI}=691.6571+0.5977 \mathrm{X}$, $\left.\mathrm{r}^{2}=0.33\right)($ Table 4)

The comparison between the means of the treatment with inorganic trace minerals premix with each one of the others (Table 4$)$ showed a difference $(\mathrm{P}<0.05)$ in the daily weight gain and in feed conversion only for the treatment in which the supplementation was not done during all the experimental period, and this indicates, therefore, that even the lowest level of inclusion of the organic trace minerals premix $(25 \%)$ promoted similar performance results to the piglets which received the inorganic trace minerals premix at $100 \%$ of dosage.

Similar results were verified by Creech et al. (2004), in an experiment with pigs in the weaning and growth phases, fed controlled diets containing normal levels of inorganic minerals $(\mathrm{Zn}, \mathrm{Cu}, \mathrm{Fe}$ and $\mathrm{Mn})$ or fed diets containing minerals from organic sources in reduced quantities, and no significant difference in the performance of the animals was verified.

Table 4 - Performance of piglets fed diets containing organic and inorganic trace minerals premixes

\begin{tabular}{|c|c|c|c|c|c|c|c|c|}
\hline \multirow{3}{*}{ Variable } & \multicolumn{6}{|c|}{ Level of trace minerals premix } & \multirow{3}{*}{ Regression } & \multirow{3}{*}{$\mathrm{CV}(\%)$} \\
\hline & \multicolumn{5}{|c|}{ Organic } & \multirow{2}{*}{$\begin{array}{c}\text { Inorganic } \\
100 \%\end{array}$} & & \\
\hline & $0 \%$ & $25 \%$ & $50 \%$ & $75 \%$ & $100 \%$ & & & \\
\hline Daily feed intake (g) & 261 & 265 & 242 & 251 & 250 & 246 & NS & 10.99 \\
\hline Daily weight gain (g) & 172 & 172 & 151 & 163 & 170 & 158 & NS & 13.42 \\
\hline Feed conversion $(\mathrm{g})$ & 1.53 & 1.55 & 1.62 & 1.55 & 1.48 & 1.56 & NS & 7.84 \\
\hline Daily feed intake (g) & 562 & 568 & 557 & 577 & 565 & 558 & NS & 7.26 \\
\hline Daily weight gain (g) & 326 & 348 & 350 & 353 & 357 & 343 & $\mathrm{~L}$ & 7.13 \\
\hline Feed conversion $(\mathrm{g})$ & 1.74 & 1.64 & 1.59 & .64 & 1.58 & 1.63 & $\mathrm{~L}$ & 6.38 \\
\hline \multicolumn{9}{|l|}{21 to 63 days of age } \\
\hline Daily feed intake (g) & 663 & 737 & 734 & 738 & 737 & 717 & $\mathrm{~L}$ & 7.65 \\
\hline
\end{tabular}


The possibility of reducing the level of inclusion of trace minerals in diets was also verified by Veum et al. (1995), Fremaut (2003) and Burkett et al. (2005), once better performance results of pigs were observed when the levels of addition of trace minerals was reduced in $50 \%$, $30 \%$ and $50 \%$ in relation to the normal levels, respectively, considering an addition in the organic form, corroborating the results of the present investigation.

The negative effects of the lack of supplementation of trace minerals in diets became more pronounced over the experimental period, which was the reason why no difference between the treatments was verified in the first 32 days of experiment, and it suggests that body reserves of trace minerals were enough to meet the requirements of piglets during this period.

Moreover, Nunes et al. (2002) found that the removal of mineral premix of the diet for finishing barrows did not influence weight gain or feed conversion, which can be explained by the lower mineral requirement of pigs closer to the slaughter commercial weigh.

The first two weeks post-weaning are considered critical due to the weaning stress and the physiological and immunological limitations of piglets, which predisposes a decrease in performance and occurrence of diarrhea (Bertol, 1997); however, no effect of treatments was verified on the incidence of diarrhea in piglets (Table 4), probably due to a low environmental contamination, once facilities had been cleaned, disinfected and there was a long period of fallowing before the beginning of the experiment, associated with an adequate weight of piglets in the weaning phase.

Increasing the levels of addition of organic mineral premix determined a linear increase $(\mathrm{P}<0.01)$ in the concentrations of $\mathrm{Cu}$ and $\mathrm{Zn}$ in the feces (Table 5). The results obtained are in accordance with those described by Creech et al. (2004) with pigs in all the production stages, who also verified that animals fed diets with lower levels of inclusion of trace minerals inclusion presented lower excretion in feces.

The comparison between the means of the treatment containing inorganic trace minerals premix with the other treatments showed that levels of inclusion of organic trace minerals premix up to $75 \%$ resulted in lower contents of $\mathrm{Cu}$ and $\mathrm{Zn}$ in the feces (Table 5).

In this experiment, there was no superior results of the performance of piglets fed diets containing organic sources of trace minerals in relation to those which received inorganic sources, but it pointed the possibility of using organic trace mineral premix at lower levels, aiming at the same productive efficiency and decrease in the excretion of trace minerals.

Increasing levels of organic trace mineral premix in the diets showed a quadratic effect $(\mathrm{P}<0.01)$ on the values of hematocrit $\left(\mathrm{Ht}=33.6489+0.1183 \mathrm{X}-0.0008 \mathrm{X} 2, \mathrm{r}^{2}=\right.$ 0.64), hemoglobin $\left(\mathrm{Hb}=9.7833+0.0341 \mathrm{X}-0.0002 \mathrm{X} 2, \mathrm{r}^{2}=\right.$ $0.68)$, mean corpuscular hemoglobin $(\mathrm{MCH}=15.5758+$ $\left.0.0445 X-0.0002 X 2, r^{2}=0.74\right)$, mean corpuscular volume $\left(\mathrm{MCV}=53.3704+0.1686 \mathrm{X}-0.0010 \mathrm{X} 2, \mathrm{r}^{2}=0.77\right)$ and platelets $\left(\mathrm{Pt}=5.7731-0.0036 \mathrm{X}+0.000023 \mathrm{X} 2, \mathrm{r}^{2}=0.54\right)$ (Table 6). Considering the regression equations, the mean recommended level of inclusion of organic trace minerals premix is $82 \%$.

In the comparison of means of the treatment containing inorganic trace minerals premix with the others (Table 6), it was verified that animals fed diets without trace minerals premix showed lower values $(\mathrm{P}<0.05)$ of hematocrit $(14.28 \%)$, hemoglobin (14.47\%), mean corpuscular hemoglobin (10.93\%), mean corpuscular volume (10.80\%) and higher values of platelets (22.73\%), as an indicative of microcytic hypochromic anemia, which is the main cause of iron and copper deficiency, while animals fed diets containing $25 \%$ inclusion of organic trace minerals premix presented lower values $(\mathrm{P}<0.05)$ of hematocrit $(5.87 \%)$ and hemoglobin $(6.93 \%)$, although these values are in accordance with normal physiological values, once, as described by Pound \& Houpt (1978), normal values of pigs hematocrit are between 30 and $45 \%$, and this can vary with the age and the method of determination, and as described by Kaneko (1989), the hemoglobin content of pigs varies between 10 and $16 \mathrm{~g} / \mathrm{dL}$. Garcia-Navarro \& Pachally (1994) cited as normal values to pigs, between 32 and $50 \%$ and between 10 to $17 \mathrm{~g} / \mathrm{dL}$ hematocrit and hemoglobin, respectively.

Table 5 - Concentrations of minerals in fecal dry matter of piglets fed diets containing different levels of organic or inorganic trace minerals premix

\begin{tabular}{|c|c|c|c|c|c|c|c|c|c|}
\hline & & \multicolumn{6}{|c|}{ Level of trace minerals premix } & \multirow{3}{*}{ Regression } & \multirow{3}{*}{$\mathrm{CV}(\%)$} \\
\hline & & \multicolumn{5}{|c|}{ Organic } & \multirow{2}{*}{$\begin{array}{c}\text { Inorganic } \\
100 \%\end{array}$} & & \\
\hline & & $0 \%$ & $25 \%$ & $50 \%$ & $75 \%$ & $100 \%$ & & & \\
\hline $\mathrm{Zn}(\mathrm{ppm})$ & Feces & $323.71 \mathrm{~b}$ & $574.66 \mathrm{~b}$ & $758.11 b$ & $1085.46 \mathrm{~b}$ & $1313.85 \mathrm{a}$ & $1257.35 \mathrm{a}$ & $\mathrm{L}$ & 13.85 \\
\hline
\end{tabular}

Means of each level of organic trace minerals premix followed by different letters in the row differ from the treatment with inorganic trace minerals premix by the Dunnett-Hsu test $(\mathrm{P}<0.05)$.

$\mathrm{L}$ - linear effect $(\mathrm{P}<0.01)$. 
Table 6 - Mean hematological profile of piglets fed diets containing levels of organic or inorganic trace minerals premix

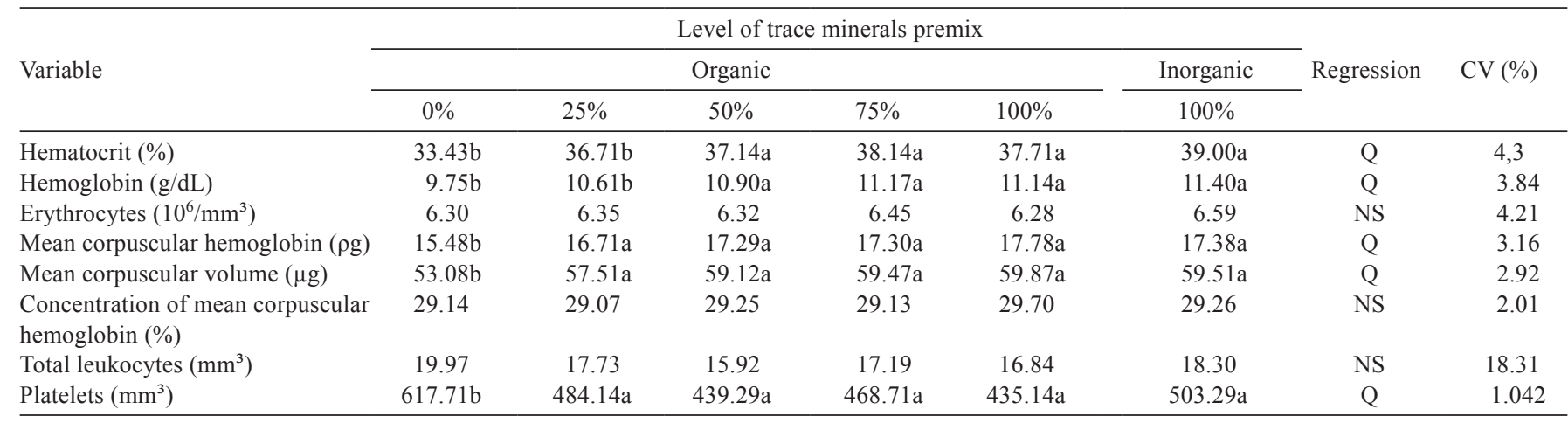

$\mathrm{Q}$ - quadratic effect $(\mathrm{P}<0.01)$; CV - coefficient of variation; NS - non significant $(\mathrm{P}>0.05)$.

Means of each level of organic trace minerals premix followed by different letters in the row differ from the treatment with inorganic trace minerals premix by the Dunnett-Hsu test $(\mathrm{P}<0.05)$.

Mamani (1996) and Arantes et al. (2007) did not find significant differences in piglets fed diets containing levels of $\mathrm{Zn}$ in the organic form, varying from 0 and 2500 ppm; however Rupic et al. (1998) verified that the organic source of zinc $\left(\mathrm{ZnSO}_{4}\right)$ determined an increase in some hematological parameters, such as erythrocytes, hemoglobin and platelets, while the zinc of organic source (methionine zinc) increased the mean corpuscular volume, which suggests that organic and inorganic sources of minerals can go through different metabolic pathways in the organism of the animal.

Moreover, Creech et al. (2004) verified higher hemoglobin concentrations in piglets in the weaning phase, which received a reduced supplementation of chelated trace minerals when compared with animals fed diets supplemented with trace minerals in the inorganic form.

As described by Wallach \& Kanaan (2003), the number of platelets increases in iron deficiency anemia, and in the present investigation, the higher number of platelets in animals not fed diets containing trace minerals is a consequence of anemia, once the values of hematocrit, hemoglobin, mean corpuscular hemoglobin and mean corpuscular volume were also lower in these animals.

The inorganic trace minerals premix presented superior levels of iron, copper, manganese and zinc in comparison with the organic trace minerals premix (Table 1); however, even at lower levels in the diet, the organic trace minerals premix promoted similar responses to performance and hematological parameters of the animals, suggesting a higher bioavailability of organic sources of minerals to weaned piglets.

\section{Conclusions}

The inorganic trace minerals premix can be substituted by the organic trace minerals premix at a lower level of inclusion in diets for weaned piglets.

\section{References}

ARANTES, V.M.; THOMAZ, M.C.; KRONKA, R.N. et al. Níveis de zinco na dieta de leitões recém-desmamados sobre o perfil de parâmetros sangüíneos. Ciência Animal Brasileira, v.8, n.2, p.193-205, 2007.

BERTOL, T.M. Alimentação dos leitões no aleitamento e creche. In: CURSO DE SUINOCULTURA, 1997, Concórdia. Anais... Concórdia: Embrapa Suínos e Aves, 1997. p.93-106.

BURKETT, J.L.; STALDER, K.J.; SCHWAB, C.R. et al. Growth comparison and fecal mineral excretion of inorganic and organic trace mineral supplementation in swine. Iowa State University Animal Industry Report. 8p. 2005.

CREECH, B.L.; SPEARS, J.W.; FLOWERS, W.L. et al. Effect of dietary trace mineral concentration and source (inorganic vs. chelated) on performance, mineral status, and fecal mineral excretion in pigs from weaning through finishing. Journal of Animal Science, v.82, p.2140-2147, 2004.

FREMAUT, D. Trace mineral proteinates in modern pig production: reducing mineral excretion without sacrificing performance. In: NUTRITIONAL BIOTECHNOLOGY IN THE FEED AND FOOD INDUSTRIES, 2003. Proceedings... Alltech's Nineteenth Annual Symposium, Nottingham University Press, Nottingham, UK, 2003. p.171-178.

GARCIA-NAVARRO, C.E.; PACHALLY,J.R. Manual de hematologia veterinária. São Paulo: Livraria Varela, 1994. 169p.

KANEKO, J.J. Clinical biochemestry of domestic animals. 4.ed. California: Academic Press, 1989. 932p.

MAMANI, N.J.P. Efeitos da suplementação de altos níveis dietéticos de cobre e zinco no desempenho de leitões. 1996. 62f. Dissertação (Mestrado em Agronomia) - Escola Superior de Agricultura "Luiz de Queiroz"/Universidade de São Paulo, Piracicaba.

MUNIZ, M.H.B. Minerais de fontes orgânicas em dietas de leitões desmamados. 2007. 67f. Tese (Doutorado em Zootecnia) Faculdade de Medicina Veterinária e Zootecnia/Universidade Estadual Paulista, Botucatu. 
NUNES, R.C.; KRONKA, R.N.; SOBESTIANKSY, J. et al. Retirada do suplemento micromineral e/ou vitamínico da ração de suínos em fase de terminação. Desempenho, níveis de minerais nos metacarpos e custo da ração. Ciência Animal Brasileira, v.3, p.49-57, 2002.

POUND, W.G.; HOUPT, K.A. The biology of the pig. London: Cornell University Press, 1978. p.245-275.

ROSTAGNO, H.S.; ALBINO, L.F.T.; DONZELE, J.L. et al. Composição de alimentos e exigências nutricionais (Tabelas brasileiras para aves e suínos). Viçosa, MG: UFV, 2005. 186p.
RUPIC, V.; IVANDIJA, L.; LUTEROTTI, S. et al. Plasma proteins and hematological parameters in fattening pigs fed different sources of dietary zinc. Acta Veterinaria Hungarica, v.46, p.111-123, 1998.

VEUM, T.L.; BOLLINGER, D.W.; ELLERSIECK, M.R. et al. Proteinated trace minerals and condensed fish protein digest in weanling pig diets Journal of Animal Science, v.73 (Suppl.1), p.308, 1995

WALLACH, J.; KANAAN, S. Interpretação de exames laboratoriais. Rio de Janeiro: Medsi, 2003. 1067p. 